Oral Tradition, 2/2-3 (1987): 633-44

\title{
The Judeo-Spanish Ballad Tradition
}

\section{Samuel G. Armistead and Joseph H. Silverman}

As the repertoire of an isolated, archaizing minority, which has lived for centuries in contact with Balkan, Near Eastern, and North African cultures, the ballad tradition of the Spanish-speaking Sephardic Jews constitutes one of the most distinctive and interesting branches of the Hispanic romancero. In regard to its archaism, Judeo-Spanish balladry is comparable, perhaps, to that of other Hispanic lateral areas, such as the Portuguese tradition of Trás-os-Montes, the Azores, and Madeira or the Castilian repertoires of León and Zamora Provinces and of the Canary Islands. ${ }^{1}$ In a Pan-European perspective, one could compare the Sephardic tradition with that of Iceland and the Faroe Islands $;^{2}$ of the German speech-island of Gottschee (Slovenia) and, to a lesser degree, of other, more recently settled "East German" communities;" or again with the folksongs of French Canada and Louisiana, or even, perhaps, with certain features of Anglo-American balladry. ${ }^{4}$

Exiled from Spain in 1492, the Spanish Jews (Sephardim) settled in various Mediterranean areas, but their Hispanic language and culture have only survived down to the present at two geographic extremes: on one hand, in the Balkans, Turkey, and the Near East and, on the other, in various towns in Northern Morocco. Apart from these modern traditions, we have only limited documentation of Sephardic balladry at earlier stages in its development. As far as narrative themes are concerned, we can form a certain idea of what the early Eastern Sephardic ballad repertoire was like during the first century of the Diaspora, in that numerous first verses (incipits) or key internal verses were used as tune indicators in collections of Hebrew hymns (piyutim) dating from as early as $1525 . .^{5}$ On the basis of such evidence, sixteenthcentury Eastern balladry turns out to have been 
somewhat different and significantly richer in narrative themes than its modern counterpart. The contrafact hymn tradition continued up through the nineteenth century, and there is also limited evidence of such incipits for Morocco in the late 1700s and early 1800s, thus giving us at least a fragmentary glimpse of the North African tradition at an earlier stage in its traditional trajectory. ${ }^{6}$ The first full text of a Sephardic ballad to be discovered so far was sung by the false Messiah, Shabbethai Zevi, and written down in a Dutch translation at Izmir (Turkey) in $1667 .^{7} \mathrm{We}$ also have versions of three traditional ballads, transcribed in a characteristic mixture of Spanish and Portuguese, from the Sephardim of Holland in a manuscript miscellany dated $1683 .{ }^{8}$ There is equivocal evidence of Spanish ballads being sung by a Sephardic Jew (or a Morisco?) in Tunis in 1746, but no Tunisian texts survive and no modern Tunisian Jews speak Spanish as their native language. ${ }^{9}$ From Eastern areas, however, handwritten Judeo-Spanish ballads first appear in the early 1700s and become relatively abundant by the end of the eighteenth century. By that time, the texts have become quite similar to those that will begin to be collected in large numbers from the late 1800 s until the present. ${ }^{10}$

Today the Eastern and North African traditions have quite distinctive characteristics. In the East, the repertoire has experienced a radical transformation vis à vis its Hispanic origins; texts have become shorter and lyric elements tend to be emphasized; ballad music has been assimilated to the Balkan-Near Eastern musical idiom; narrative themes and stylistic features have also been borrowed from Greek, Turkish, and Arabic traditional poetry; contacts with the modern Spanish ballad are minimal or essentially non-existent; and ballad language has remained archaic, preserving many phonological features in common with medieval Spanish. ${ }^{11}$ In Morocco, on the other hand, ballad texts are still remarkably close to their sixteenth-century Peninsular congeners; obviously, they have also undergone their own evolution, but an overall impression of textual conservatism is striking; the music is essentially Hispanic and Western in character; the language has been largely assimilated to a slightly substandard modern Andalusian colloquial Spanish, with features of the earlier Judeo-Spanish dialect (hakitía) surviving only as an occasional substrate influence; and there has been a massive infusion of modern Peninsular ballads, which imparts to the basically archaic Moroccan repertoire a decidedly mixed, eclectic character. ${ }^{12}$ 
It is difficult, if not impossible, to identify specific Peninsular regional characteristics in the Sephardic subtraditions that might indicate the ballads' origin in one or another area of Spain. Just as in the language (Révah 1980-84), the ballad repertoire has been reformed into a local koine, in which early regional variations seem to have been largely obliterated by subsequent developments. Even so, a number of Moroccan texts show particular affinities to Peninsular traditions of the South and East. ${ }^{13}$ (But do such characteristics go all the way back to the fifteenth-century Diaspora?) In the East, various text-types are known today on the Peninsula only in Catalonia, ${ }^{14}$ but such data tell us little about the origins of the tradition as a whole, which, like the Jewish exiles themselves, must have originated in almost every region of the Iberian Peninsula.

The Sephardic repertoire includes narrative types from almost all the thematic categories present in the other Hispanic subtraditions. The only obvious exception is, of course, the abundant Peninsular and Hispano-American balladry concerned with events in the New Testament and the Apocrypha. In all other thematic categories, the Judeo-Spanish tradition is richly representative and includes many early (fifteenth- and sixteenth-century) text-types that survive nowhere else in the modern tradition. The role of Sephardic balladry as an aid to reconstructing earlier stages of the Hispanic tradition is, of course, crucial. A number of Sephardic ballads perpetuate narratives that were current in the medieval Castilian and French traditional epic, and a majority of the epic-based songs derive, in direct oral tradition, from such medieval poems. There are, then, Sephardic ballads ultimately related to the Cantar de Mio Cid (Poem of the Cid), to the Mocedades de Rodrigo (Early Adventures of the Cid), to Roncesvalles (the Spanish adaptation of the Roland), to La Mort Aymeri de Narbonne, to Beuve de Hantone, and to other epic narratives as well. ${ }^{15}$ Many Sephardic ballads concern events in Spanish and Portuguese history, and some that can be dated after 1492-The Death of the Duke of Gandia, The Exile of the Jews from Portugal, and The Death of Prince John (all three reflecting events of the year 1497) - point to post-diasporic contacts between the Jewish exile communities and the Iberian Peninsula, most probably through late emigration of cristianos nuevos (New Christians), eager to reembrace their Jewish faith rather than endure further inquisitorial persecution. ${ }^{16}$ The Sephardic repertoire 
attests to the continued function of ballads as a record of current events (noticierismo): The Death of King Sebastian (1578), Philip II's Testament (1598), or even the modern Moroccan Revolt of the Beni Ider. ${ }^{17}$ Biblical ballads - at least with respect to songs in "authentic" octosyllabic romance meter-are less frequently encountered than might be expected. With a few exceptions, all these songs are (or were) also known in the Christian Spanish tradition: Sacrifice of Isaac, Rape of Dinah, David and Goliath, Thamar and Amnon, David Mourns Absalom, Solomon's Judgment. Two romances about Moses and another on the martyrdom of Hannah's sons appear to be exclusively Sephardic. The Crossing of the Red Sea is unique, in that it is sung only in Greece and Turkey, on one hand, and, on the other, for ritual purposes by a Crypto-Jewish remnant population in northeastern Portugal. There are a number of Judeo-Spanish ballads concerned with classical antiquity: Paris' Judgment, The Abduction of Helen, The Death of Alexander, Tarquin and Lucrece, and Virgil (who is imprisoned for seducing the king's niece). Such ballads doubtless ultimately derive from medieval adaptations of classical narratives.

There are numerous Judeo-Spanish romances concerning a great variety of novelesque themes: prisoners and captives; the husband's return; faithful or unhappy love; the unfortunate wife; the adulteress; female killers; rape and abduction; incest; seductive or seduced women; other amorous adventures; tricks and deceptions; religious themes; death personified; animals; and various other subjects. A number of these narratives are clearly of medieval provenance: The Sisters; Queen and Captive (from Fleur et Blanchefleur); Don Bueso and his Sister (the Kudrun story); the é assonant Husband's Return (with a French balladic precursor dating from the fifteenth century); The Weeping Knight (from an erudite ballad written before 1498); the $o$ assonant Adulteress (ultimately related to an Old French fabliau, Le Chevalier à la robe vermeille); The Beauty in Church (brought from Greece to Spain, through Catalonia, during the fourteenth-century Catalan occupation of Athens); The Lady and the Shepherd (derived from the first known Hispanic ballad, written down in 1421); among other narratives that could be cited. The presence of numerous Christian elements (the Virgin, the Pope, priests, nuns, churches, crosses, mass, baptism, pork as food, and many others), in evidence even in the long-isolated Eastern tradition, also clearly bespeaks the Sephardic ballads' medieval Hispanic ancestry. ${ }^{18}$ Other songs, 


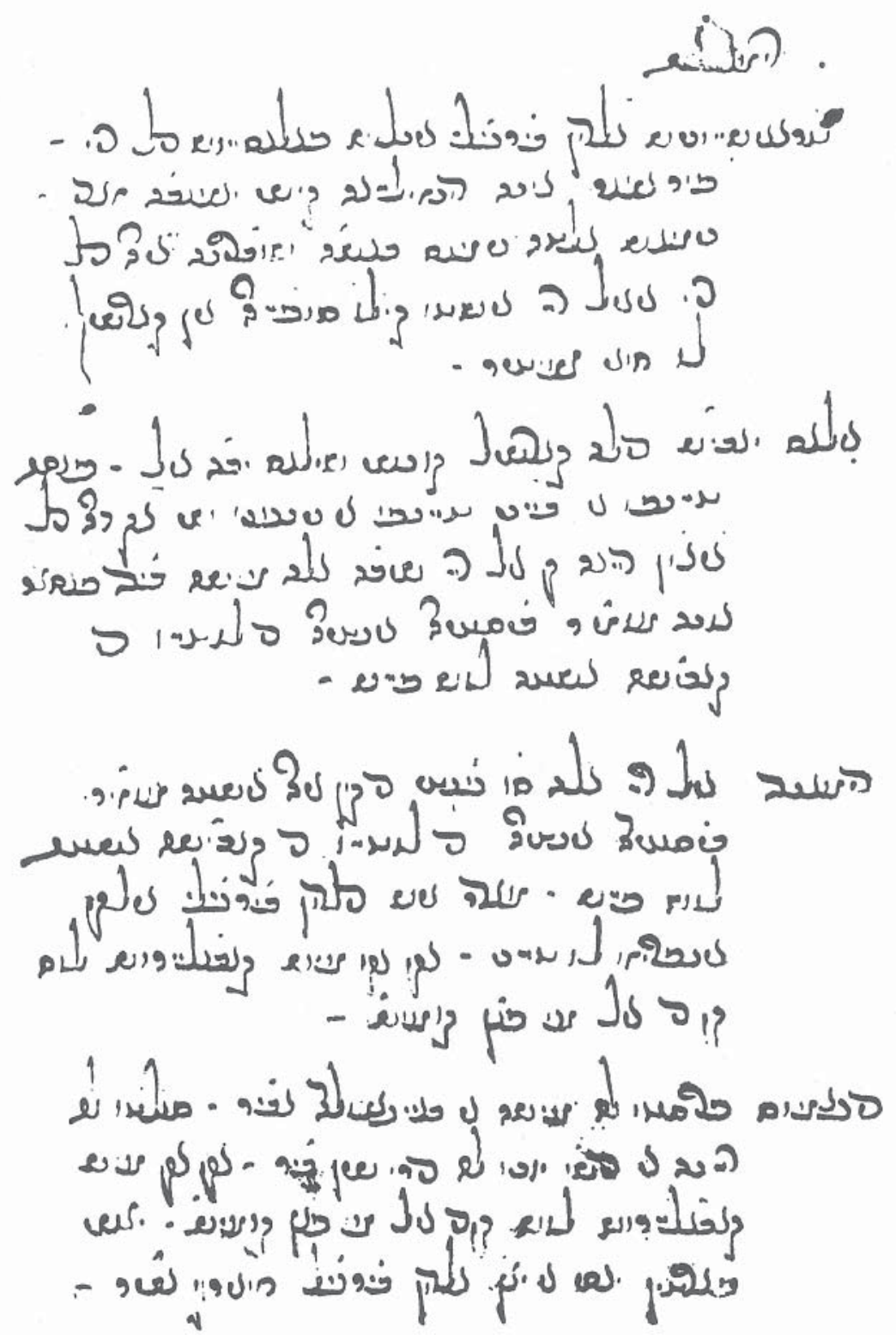

The ballad of Virgil, from an eighteenth-century Bosnian Sephardic manuscript (J.N.U.L., MS Heb. $8^{\circ}$ 2946) (Armistead and Silverman 1971b). 
for a variety of reasons - style among them-are obviously of late origin: The Child Murderess; The Girl who Killed her Sister for Love of her Brother-in-law, The Rag Merchants'Bonnet Maker; The Miserly Sister (blood flows from the bread denied to an impoverished sibling). Many modern Spanish ballads reached Morocco quite recently, as we have seen, and in exile the Sephardim, both in the East and in North Africa, continued to compose narrative songs in romance meter. Such are Eastern romances like Condemned by the Pasha, The Renegade Girl, and The King's Favorite, with their clearly Oriental ambience, ${ }^{19}$ or the equally Moroccan Carnations and Beatings, The Jealous Christian, and The Revolt of the Beni Ider. ${ }^{20}$ The Death of King Sebastian, celebrating, from a Jewish perspective, the disaster of Alcazarquivir in 1578, was also obviously composed by Moroccan Sephardim.

Many narrative types current among the Spanish Jews recall ballads known throughout Europe. Some of these similarities seem to be coincidental (Moriana's Poison and the Anglo-Scottish Lord Randal, for example), but a majority certainly imply genetic relationships. There are, for instance, probable (though distant) Sephardic congeners of the following ballads in the Anglo-Scottish tradition: Lady Isabel and the Elf-Knight (Child 4); Hind Horn (17); Clerk Colville (42); Twa Magicians (44); Young Beichan (53); Fair Annie (62); Lady Maisry (65); Lord Thomas and Fair Annet (73); Maid Freed from the Gallows (95); Baffled Knight (112); Mother's Malison (216); Our Goodman (274); and possibly several others. Similar correlations can be established with Scandinavian, German, Italian, and French balladry, as well as with repertoires even further afield, such as that of Rumania. ${ }^{21}$ France doubtless links Iberia to the Continent and the sources of many Hispanic ballads are certainly to be found in French chansons populaires.

One of the most striking features of Eastern Sephardic balladry is embodied in a variety of narrative themes adapted from modern Greek tragoúdia. Such Judeo-Spanish romances as The Bottomless Well, The Daughter's Dream, The Newly Married Galley Slave, and Death and the Girl have close, sometimes even verbal, correspondences with Greek ballads. ${ }^{22}$ The Cursed Son's Return embodies a particularly apt characterization of the Judeo-Spanish tradition in its intricate juxtaposition of medieval Spanish elements-in the initial and concluding segments - with a narrative adapted from the modern Greek ballad of The Evil Mother. ${ }^{23}$ To offer our readers at least one example of a Sephardic ballad, here 
is a version of The Cursed Son's Return, as sung by Mrs. Leah Huniu, from the Island of Rhodes (in Los Angeles, July 31, 1959):

—¿Di Qué yoráx, Blancailiña, de qué yoráx, Blancaiflor?

2 - Yoru pur vos, cavayeru, que vos vax y me dixáx. Mi dixáx niña y muchacha, chica di la poca idat.

4 Me dixáx hijos chiquetos, yoran y dimandan pan. Mitió la mano al su pechu, sien liras li fue a dar. - ¿Estu para qué m'abasta, para el vino o para'l pan? - Vendiréx viñas y campus, media parti de sivdat. - ¿Estu para ké m'abasta, para el vino o para'l pan? - Vendiréx los mis vestidus sen sudar i sen manchar. - ¿Y esto para qué me abasta u para el vinu, para'l pan? - Si estu nu vus abasta, vus prometu pur cazar. Esto que sintió su madri, maldisión le fue a'char: - Todas las navis dil puertu vaigan i tornin sin sar. La nave de el me hiju vaiga y no torn'atrás. S'aparósi a la vintana, la qui da para la mar. Vido vinir navis frankas, navigando pur la mar. - Así viva'l capitañu que me digas la virdat. Si's que vitis al mi hiju, al mi hiju carunal.

- Yo lu vide a tu hiju ichadu en l'arinar; una piedra pur kavesal, l'arena pur kovyirtal. Estu que sintió su madri, eya si mitio a yurar.

- No yoréx vos, la mi madre, que so tu hiju carunal. ${ }^{24}$
"Why are you weeping, Blancalinda?

Why are you weeping, Blancaflor?"

"I'm weeping for you, my lord, for you are leaving me.

You leave me a young girl, only a child in years.

You leave me with little children, who weep and beg for bread." He put his hand in his pocket and gave her a hundred liras. "What good is this to me for buying bread or wine?" "You can sell fields and vineyards and half of all the city." "What good is this to me for buying bread or wine?" "You can sell my clothes, neither sweated nor soiled." "And what good is this to me for buying bread or wine?" "If this is not enough, I promise to marry you off." When his mother heard this, she put a curse on him: "May all the ships in port go and return without grief. And may my son's ship go and never return!" She stood by the window, the window that looks out to sea. She saw foreign ships come, sailing across the sea:

"Long may you live, my captain, if you will tell me the truth.

Have you seen my son, that son so dear to my heart?" "Yes, I have seen your son, he was lying on the sand, with a stone for a pillow and the sand for a coverlet."

When his mother heard this, she began to weep.

"Don't weep, my mother, for I am your dear son."

Verses 1-11 and 21-22 are based on the early Spanish ballad of Count Dirlos, first printed around 1510, but the rest, the core of the narrative, closely parallels a modern Greek ballad, The Evil 


\section{$\rightarrow$

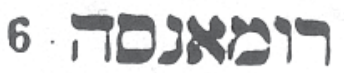

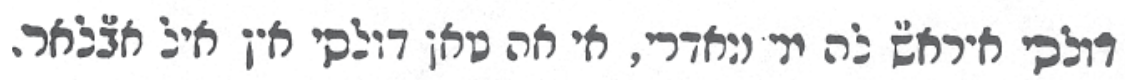

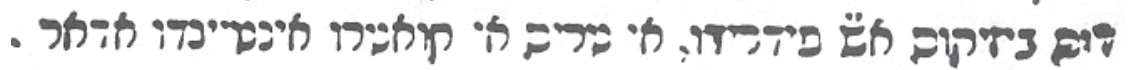

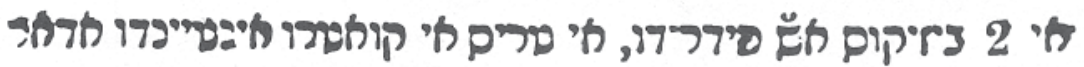

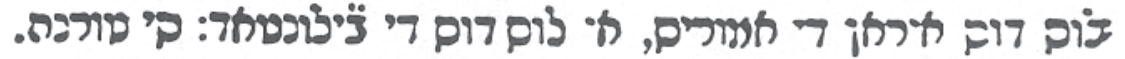

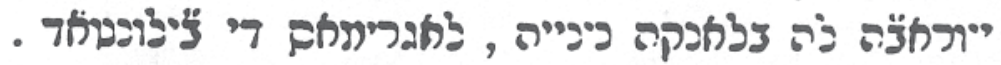

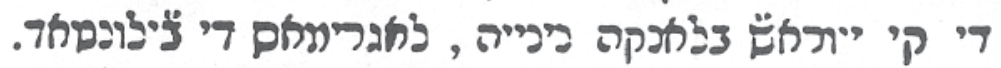

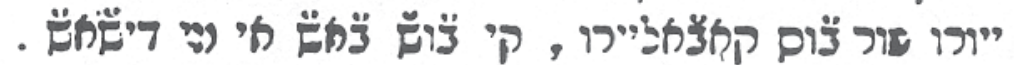

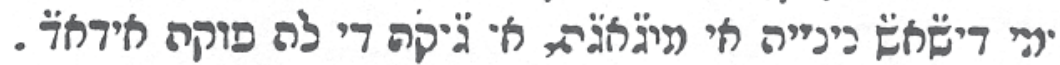

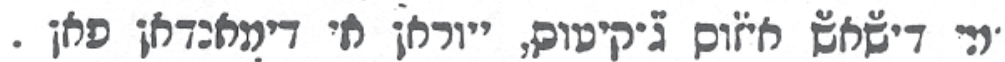

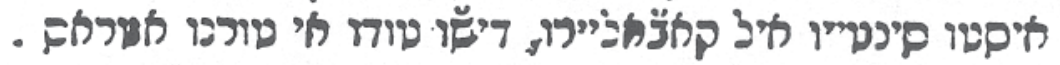

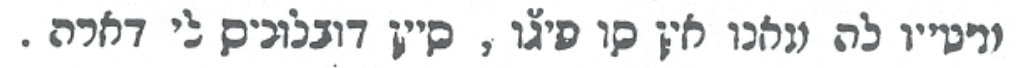

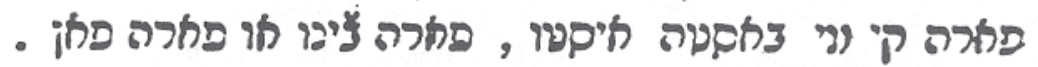

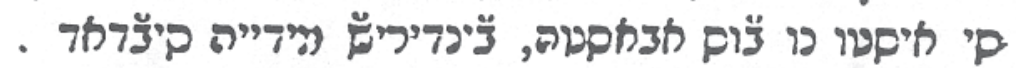

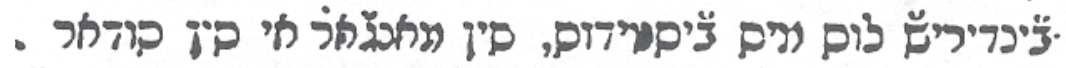

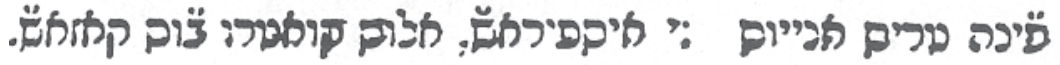

The Cursed Son's Return, from the Hebrew-letter chapbook, Güerta de romansas antiguas de pasatiempo ([Salonika?], before 1908), belonging to the Menéndez Pidal Archive in Madrid (Armistead and Silverman 1971a). 
Mother. Entire narratives are not the only Balkan or Near Eastern features present in the Eastern Sephardic repertoire. Turkish, or rather Pan-Balkan, exclamations (amán, ğanim, vay) punctuate many songs, and Eastern ballad music has, as we have seen, been assimilated to Oriental norms. Imagery, too, is sometimes of Eastern origin, as when a young man's stature is compared to a cypress tree, using the Turkish word selvi, as also in Greek (kyparíssa) and other Balkan languages. ${ }^{25}$ Some Eastern Sephardic ballads have, demonstrably, been translated from French or Italian; such are The Diver, Fishing for a Ring, and The False Pilgrim. ${ }^{26}$ Thus, from the perspective of its many and variegated extra-Hispanic elements, the Sephardic romancero can be characterized not only as a precious treasury of medieval survivals, but also as a richly eclectic tradition, to which all the many peoples-Hispanic, Mediterranean, Balkan, Near Eastern, Christian, and Muslim-with whom the Sephardim came into contact have made their distinctive contributions.

Modern collecting of Judeo-Spanish balladry began in the East in the late nineteenth century and in Morocco during the first decade of the twentieth. Emigrant populations in Israel and in North and South America have also been a major source of texts. ${ }^{27}$ The most ample and significant collections for the Eastern tradition are those of Attias (1961), Benmayor (1979), Crews (1979), and Hemsi (1932-73), as well as the various sources we have edited. ${ }^{28}$ For Morocco, the collections of Bénichou (1968b), Larrea Palacín (1952), Librowicz (1980), Martínez Ruiz (1963), and Nahón (Armistead, Silverman, and Librowicz 1977) are indispensable. The Benardete collection (Armistead and Silverman 1981b), formed among immigrants in New York in 1922-1923, and Isaac Levy's four volumes (1959-1973), collected in Israel, include texts from both the East and Morocco, as do the massive collections - still largely unedited-of the Menéndez Pidal Archive in Madrid (some 2,150 texts) and Armistead, Silverman, and Katz (some 1,485 texts). ${ }^{29}$ Today, a corpus of several thousand texts, both edited and unedited, makes possible detailed comparative studies of the traditional development of individual themes, of thematic differences between various regional repertoires, and of creativity in oral tradition, among many other subjects. Ultimately, Sephardic balladry can only be studied as but one component of the Pan-Hispanic tradition, in conjunction with ballads from Castilian areas of Spain and from the Canary Islands and Spanish America; 
from Portugal and Galicia, the Atlantic Islands, and Brazil; and from Catalonia, in its various regional subtraditions. ${ }^{30}$ In such a Pan-Hispanic perspective, the Judeo-Spanish tradition has played and will continue to play a crucial role in the diverse research orientations currently being developed by ballad studies as a burgeoning subdiscipline of Hispanism: historical and source work, comparative studies of European congeners, ballad geography, music, bibliography and cataloguing, literary criticism, oral creativity, sociological perspectives, formulism, semiotics, and computerized investigations. ${ }^{31}$

The most recent fieldwork on both branches of the Sephardic tradition, but especially among Eastern singers, reveals a steadily decreasing repertoire, in which in general only the more common themes continue to be sung by an increasingly aged and diminishing group of singers. The Judeo-Spanish tradition is clearly in the final stages of a critical decline. Even so, there are surprising exceptions and, from time to time, excellent ample versions and notable rarities still continue to come to light. ${ }^{32}$ But time is running out and all efforts must be bent to saving for future study the surviving vestiges of this venerable tradition.

\author{
University of California, Davis \\ University of California, Santa Cruz
}

Notes

${ }^{1}$ For Trás-os-Montes, see Costa Fontes (1984a; and in press); also Dias Marques (1984-85); Armistead (1982a); for Azores, Costa Fontes (1983a); for Madeira, Ferré et al. (1982); for León and Zamora, Petersen et al. (1982) and Armistead (1983a); for the Canarias, Catalán et al. (1969a) and Trapero et al. (1982; 1985).

${ }^{2}$ For Iceland, see Olason (1982); for the Faroes, Wylie and Margolis (1981), particularly on the functions of ballad dancing; note the exhaustive catalog of Icelandic and Faroese text-types in Jonsson et al. (1978).

${ }^{3}$ For Gottschee, see Brednich and Suppan (1969) and, for "East German" settlements, Künzig and Werner (1975).

${ }^{4}$ For the archaism of Anglo-American ballads, see, for example, Combs (1967:5760 ); Barry et al. (1929). We know of no specific comparative study of the survival in Canada of narrative themes which have died out in France. For a sampling of the Canadian tradition, see, among others, Gagnon (1925); Barbeau's many collections (e.g. 1962); d'Harcourt (1956); for Louisiana, Whitfield (1939:34-36, 56-59, for example); Oster (1962). 
${ }^{5}$ See Avenary (1971) and Armistead and Silverman (1981a).

${ }^{6}$ See Armistead and Silverman (1973); Armistead, Hassán, and Silverman (1974).

${ }^{7}$ See Menéndez Pidal (1948); Armistead and Silverman (1971a:101-2); Scholem (1973:400-1).

${ }^{8}$ See Armistead and Silverman (1980a; 1980b).

${ }^{9}$ See Armistead (1979d). A fragment of a Judeo-Spanish ballad-obviously of Moroccan origin - has been collected on the island of Jerba (Fiore, 1969), but this cannot be counted as an authentic Tunisian text.

${ }^{10}$ See González Llubera (1938); Attias (1959; 1973); Armistead, Hassán, and Silverman (1978).

${ }^{11}$ For a detailed characterization of the Moroccan tradition, see Bénichou (1968b:30759; 1983).

${ }^{12}$ On the transformation of Eastern texts, see Catalán (1970-71:5-14); on Near Eastern music, Katz (1972-75; 1980-84); on Balkan and Near Eastern textual features, Benmayor (1978); Armistead (1979-81); Armistead and Silverman (1982; 1983-84).

${ }^{13}$ See, for example, Menéndez Pidal, Catalán, and Galmés (1954:114-15, 198-201); Catalén (1969b:195-97); Armistead, Silverman, and Katz (1986:270-73).

${ }^{14}$ See, in Armistead (1978:nos. I3, L12), the ballad types Husband's Return (á-a) and Married to an Old Man (é).

${ }^{15}$ See Armistead and Silverman (1971a:56-67; 1982:35-42); Armistead, Silverman, and Katz (1986).

${ }^{16}$ For bibliography on these romances (and others cited below by their English titles), see Armistead (1978), where ballads are indexed under both their Spanish and English titles. (1958:61-63)

${ }^{17}$ See Armistead (in press); Armistead and Silverman (1979:50-59); Larrea Palacín

${ }^{18}$ See Armistead and Silverman (1965; 1982:127-48).

${ }^{19}$ Concerning these ballads, see Benmayor (1979:no. 13); Armistead (1978:nos. 1123, U5); and Armistead and Silverman (1971b:no. C21; 1979:no. All).

${ }^{20}$ See Armistead, Silverman, and Librowicz (1977:nos. 52-57); Larrea (1958:61-63).

${ }^{21}$ See Armistead (1979b); Armistead and Katz (1978); Rechnitz (1978; 1979).

${ }^{22}$ See Armistead (1979-81); Armistead and Silverman (1982:151-78; 1983-84). Some of these Eastern ballads have migrated to Morocco.

${ }^{23}$ See Armistead and Silverman (1971a:306-14; 1982:163-68).

${ }^{24}$ This version was included in Menéndez Pidal and Goyri de Menéndez Pidal (1957$85: 3: 125-26)$. In v. 13b, the word sar is from Hebrew tsacar "anguish, affliction."

${ }^{25}$ See Armistead and Silverman (1982:194-99, 208-27). 
${ }^{26}$ See Armistead and Silverman (1982:229-39); Armistead (1978:no. I9).

${ }^{27}$ For the history of Judeo-Spanish ballad collecting in Morocco, in America, and elsewhere, see Armistead, Silverman, and Librowicz (1977: 15-22); Armistead and Silverman (1981b:4-11).

${ }^{28}$ See Armistead and Silverman (1971a; 1971b; 1982); Armistead, Silverman, and Hassán (1981c).

${ }^{29}$ For the Nahón and Bernadete collections, see Armistead, Silverman, and Librowicz (1977); Armistead and Silverman (1981b); for the Menéndez Pidal Archive, Armistead (1978); for our own collection, Armistead and Silverman (1983); Armistead, Silverman, and Katz (1986).

${ }^{30} \mathrm{On}$ the Pan-Hispanic character and distribution of the romancero, see Menéndez Pidal (1953:2:358-59). Such publications as the Romancero tradicional de las lenguas hispánicas (RT, 1957-85) and the Catálogo general (CGR, 1982-84) are Pan-Hispanic in scope.

${ }^{31}$ For recent surveys of Sephardic and Pan-Hispanic ballad research, see Armistead (1982a; 1982b; 1983b; 1985). For fundamentally important Pan-Hispanic ballad studies, in which Sephardic balladry has played a crucial role, note, among others, Bénichou (1968a). Catalán (1969b; 1970), and the CGR (1982-84).

${ }^{32}$ For the most recent collecting, see Benveniste (1986), Merrill-Mirsky (1984), Noga-Alberti (1984), W. Hamos (1982), Weich-Shahak (1984). For an example of a recently collected ballad's making a crucial contribution to our knowledge, see Armistead, Librowicz, and Silverman (1986). 